\title{
EL SISTEMA DE JUSTICIA CONSTITUCIONAL EN LA REPÚBLICA DOMINICANA Y LA LEY ORGÁNICA DEL TRIBUNAL CONSTITUCIONAL Y DE LOS PROCEDIMIENTOS CONSTITUCIONALES $(2011)^{1}$
}

\author{
Allan R. Brewer-Carías \\ Profesor de la Universidad Central de Venezuela \\ Adjunct Professor of Law, Columbia Law School (2006-2007)
}

Con fecha 8 de noviembre de 2010, el Presidente de la República Dominicana, mediante Oficio No 11339, sometió al Senado un Proyecto de Ley Orgánica del Tribunal Constitucional y de los Procesos Constitucionales, con el objeto de regular la organización del Tribunal Constitucional creado por la Constitución de enero de 2010, y "el ejercicio de la Justicia Constitucional entendida como la potestad del Tribunal Constitucional y el Poder Judicial de pronunciarse en materia constitucional en los asuntos de su competencia”.

En su comunicación, además, el Presidente resumió que

"Ia Justicia Constitucional se realiza mediante procesos y procedimientos constitucionales que tienen como objetivo sancionar las infracciones constitucionales, para garantizar la supremacia, integridad y eficacia de la Constitución, la defensa del orden constitucional, la adecuada interpretación constitucional y la protección efectiva de los derechos fundamentales".

A tal efecto, según expresó el Presidente en su comunicación, la Ley Orgánica estará regida por los siguientes principios rectores: "constitucionalidad, interdependencia, efectividad, oficiosidad, vinculatoriedad, inconvalidabilidad, favorabilidad, accesibilidad, celeridad, informalidad, gratuidad, inderogabilidad y supletoriedad".

El Presidente precisó, además, que el Proyecto buscaba definir y regular, "la Justicia Constitucional y sus principios; la organización y atribuciones del Tribu-

\footnotetext{
${ }^{1^{*}}$ Texto ampliado de la conferencia dictada en el VII Encuentro Iberoamericano de Derecho Procesal Constitucional, organizado por la Comisionaduría de Apoyo a la Reforma y Modernización de la Justicia de la República Dominicana y el Instituto Iberoamericano de Derecho Procesal Constitucional, Santo Domingo, 3 de marzo de 2010.
} 
nal Constitucional; los procesos y procedimientos constitucionales, entre los que se encuentran: el control concentrado de constitucionalidad, el control difuso de constitucionalidad y el control preventivo de los tratados internacionales; los conflictos de competencia; las acciones de habeas corpus, habeas data y amparo; los procedimientos particulares de amparo, entre los cuales se encuentran: el amparo contra actos jurisdiccionales, el amparo de cumplimiento, el amparo colectivo y el amparo electoral; la revisión constitucional de sentencias, y el procedimiento de ejecución de sentencias de la Corte Interamericana de Derechos Humanos.

Luego de las discusiones en la Cámara del Senado, el Proyecto fue discutido en la Cámara de Diputados donde fue aprobado en fecha 1 de marzo de 2011, habiendo sido devuelto al Senado mediante oficio No 201 de 4 de marzo de 2011 con el título de Ley Orgánica del Tribunal Constitucional y de los Procedimientos Constitucionales, el cual fue precedido de una serie de "Considerandos", en los cuales se motiva el mismo, expresándose entre otros aspectos sobre el "sistema robusto de justicia constitucional independiente y efectivo," que "la tutela de la justicia constitucional fue conferida, tanto al Tribunal Constitucional como al Poder Judicial, a través del control concentrado y el control difuso" (Considerando Quinto).

En ese marco, las presentes notas están destinadas a analizar globalmente este importante Proyecto de Ley (en adelante "Ley Orgánica"), en su versión de fecha 1 de marzo de 2011, en especial, sólo en lo que se refiera a sus previsiones en materia de control difuso de la constitucionalidad (III); en materia de control concentrado de la constitucionalidad, incluyendo el control a posteriori de la constitucionalidad de los actos estatales y de omisiones legislativas, el control a priori de los tratados internacionales y la solución de conflictos de competencia de orden constitucional (IV), y la revisión constitucional de sentencias constitucionales (V) y de amparo (VI) por el Tribunal Constitucional. No nos referiremos, por tanto, a los procesos constitucionales de protección de los derechos fundamentales (amparo, habeas corpus, habeas data) que también están regulados detalladamente en la Ley Orgánica (Arts. 63 a 114). Antes sin embargo, haremos algunas precisiones sobre los sistemas de justicia constitucional (I), y sobre las previsiones en la materia en la Constitución de la República Dominicana, y algunos principios generales en la Ley Orgánica (II).

\section{Algunas PRECISIONES SOBRE LOS SISTEMAS DE JUSTICIA CONSTITUCIONAL}

A los efectos de asegurarle a que en el Estado Constitucional de derecho, los órganos superiores de justicia puedan asumir el rol esencial de interpretar la Constitución y de ejercer el control de la constitucionalidad de los actos estatales, en el mundo contemporáneo y de acuerdo a las peculiaridades de cada país y de cada sistema constitucional, se ha venido estableciendo una variedad de sistemas de 
justicia constitucional, los cuales siempre se pueden clasificar tomando en cuenta lo que se haya dispuesto en relación con el o los órganos judiciales o de otra índole constitucional llamados a ejercer tal control de la constitucionalidad.

Es decir, sea cual fuere el sistema de justicia constitucional, cuando la potestad de ejercer el control de la constitucionalidad se atribuye a los órganos judiciales, éstos pueden ser o todos los jueces que integran el Poder Judicial o un solo órgano del mismo u otro órgano separado del Poder Judicial al cual se atribuye la Jurisdicción Constitucional.

De allí la clásica distinción de los sistemas de justicia constitucional según el método de control que se ejerce: en primer lugar, el llamado método difuso de control, cuando el poder para apreciar la constitucionalidad o inconstitucionalidad de las leyes y, en su caso, declarar su inconstitucionalidad, se atribuye a todos los jueces de un país, cualquiera que sea su jerarquía, y en segundo lugar, el llamado método concentrado de control, conforme al cual el poder anulatorio respecto de las leyes y demás actos estatales contrarios a la Constitución se atribuye a un solo órgano del Poder Judicial, sea a la Corte Suprema de Justicia del país o a un Tribunal Constitucional especialmente creado para ello, que incluso puede ser ubicado fuera del Poder Judicial.

Ambos sistemas de justicia constitucional, sin duda, aun cuando en su inicio respondían a principios diferentes, en muchos países coexisten en paralelo, como sucede en buena parte de los regímenes constitucionales de los países latinoamericanos y como está regulado expresamente en la Constitución de República Dominicana.

En cuanto al método difuso de control de constitucionalidad, como poder atribuido a todos los jueces para decidir sobre la inconstitucionalidad de una ley que deba aplicarse en un caso concreto, desaplicándola y aplicando preferentemente la Constitución, el mismo se lo regula expresamente en el artículo 188 de la Constitución de República Dominicana. Como en virtud de la supremacía de la Constitución, todo acto estatal contrario a la misma debe considerarse inconstitucional y nulo; todos los jueces tienen el poder-deber de apreciar dicha inconstitucionalidad. Ello es la consecuencia lógica cuando se habla de la Constitución como "norma suprema y fundamento de todo el ordenamiento jurídico" (Art. 6).

Ahora bien, correspondiendo el método difuso de control de la constitucionalidad a todos los jueces, su ejercicio se caracteriza por ser de carácter incidental, en el sentido de que se ejerce al decidirse un caso concreto, como poder que puede ejercer cualquier juez, incluso de oficio. En estos casos, en consecuencia, no se trata de un proceso constitucional que tiene por objeto específico controlar la constitucionalidad de una ley, sino de una decisión judicial que se adopta en un proceso judicial cualquiera, con su propio objeto específico, en el cual, para 
decidirlo, se aprecia la inconstitucionalidad de la ley. Por ello, la decisión que en tal sentido se adopta, sólo tiene efectos inter partes y meramente declarativos. El juez, en estos casos, no anula la ley sino sólo la considera inconstitucional y nula, por lo que la decisión tiene en principio efectos ex tunc, pro praeterito.

En relación con este método difuso de control de constitucionalidad, en el derecho comparado se ha planteado el problema de la eventual falta de uniformidad o la disparidad de decisiones que podrían adoptar los jueces de distinta jerarquía, en torno a la inconstitucionalidad de una ley, habiéndose establecido diversos correctivos en los propios sistemas constitucionales.

Uno de ellos es, por ejemplo, la asignación del carácter vinculante a las decisiones que adopte la Corte Suprema de Justicia en la materia cuando el asunto llegue a ese nivel, como sucede en los Estados Unidos de América.

Otro correctivo es, por ejemplo, la atribución a la Corte Constitucional o Tribunal Supremo de la competencia para conocer de un recurso extraordinario de revisión, como se ha establecido en las Constituciones de Colombia o Venezuela, lo que permite al Tribunal Constitucional uniformizar la jurisprudencia y resolver con carácter obligatorio y vinculante sobre el tema. Esta es la solución adoptada en la Constitución de la República Dominicana.

Adicionalmente, otro correctivo al problema se logra precisamente con el establecimiento, en paralelo, del método concentrado de control de constitucionalidad de las leyes, como también ocurre en la Constitución de República Dominicana siguiendo el modelo mixto e integral que se desarrolló inicialmente en América Latina en Colombia y Venezuela, otorgándose a las decisiones del Tribunal Constitucional el carácter de "precedentes vinculantes para los poderes públicos y todos los órganos del Estado" (Art. 184). El principio se reitera en el artículo 31 de la Ley Orgánica y, además, en el artículo 7.13, al definir el principio de la "vinculatoriedad" como uno de los principios rectores del sistema de justicia constitucional, indicando que:

"Las decisiones del Tribunal Constitucional y las interpretaciones que adoptan o hagan los tribunales internacionales en materia de derechos humanos constituyen precedentes vinculantes para los poderes públicos y todos los órganos del Estado".

Se destaca, en esta declaración, por supuesto, la importancia que significa la atribución mediante la Ley Orgánica, del carácter vinculante para el Estado de la República Dominicana que tienen las decisiones, por ejemplo, de la Corte Interamericana de Derechos Humanos.

Por otra parte, el método concentrado de control de constitucionalidad, como es sabido, tuvo su origen en América Latina y fue luego desarrollado durante el siglo pasado en Europa. Se caracteriza por la atribución a un solo órgano judicial, que puede ser el Tribunal o Corte Suprema con o sin Sala Constitucional, o un 
Tribunal Constitucional especial, del poder de conocer de la impugnación de leyes por inconstitucionalidad y de anularlas en caso de que sean contrarias a la Constitución, con efectos erga omnes. Esta última opción es la que se ha seguido en la Constitución de 2010 de la República Dominicana con la creación del Tribunal Constitucional, "para garantizar la supremacía de la Constitución, la defensa del orden constitucional y la protección de los derechos fundamentales" (Art. 184).

Sin embargo, en realidad, lo que caracteriza al método concentrado de control de constitucionalidad de las leyes no es la creación de un tribunal constitucional, sino la atribución a un solo órgano judicial o tribunal constitucional del poder anulatorio de las mismas. Es decir, lo importante es la concentración del poder anulatorio de control en un solo órgano judicial o de control constitucional, más que la forma o naturaleza que puede tener el mismo.

Este método concentrado de control de la constitucionalidad, a diferencia del método difuso, como se ha dicho, se ejerce en un proceso en el cual su objeto principal es, precisamente, el juzgamiento de la inconstitucionalidad de una ley, la cual puede consistir en una decisión anulatoria de la misma, con efectos generales, erga omnes, y en general ex nunc, es decir, pro futuro teniendo la decisión en consecuencia, carácter constitutivo.

El método concentrado de control, por otra parte, puede ser previo o posterior, según que se pueda ejercer contra leyes antes de que entren en vigencia o sólo una vez que están vigentes. En el caso de la República Dominicana, el control concentrado de la constitucionalidad de las leyes en general es a posteriori, regulándose sin embargo un control en forma a priori respecto de "los tratados internacionales antes de su ratificación por el órgano legislativo” (Art. 185,2), como también, por ejemplo, sucede en Colombia y en Venezuela.

El método concentrado de control, además, puede ser principal o incidental, según que la cuestión de la inconstitucionalidad de la ley llegue al juez constitucional por vía de una acción de inconstitucionalidad, la cual incluso en algunos casos, como sucede en Colombia, Panamá y Venezuela, puede ser una acción popular; o que llegue por vía incidental, por una incidencia planteada en un juicio concreto, como excepción de inconstitucionalidad, lo cual no sucede por supuesto, cuando se establece en paralelo el control difuso de constitucionalidad, como es el caso de los sistemas mixtos o integrales, como el que se establece en la República Dominicana.

Por último, además del método difuso y concentrado de control de la constitucionalidad de la legislación existente, en el mundo contemporáneo también se han venido desarrollando mecanismos de control de la constitucionalidad de las omisiones del Legislador, cuando ha dejado de sancionar leyes indispensables 
para la completa aplicación o vigencia de la Constitución. Se trata del control de la constitucionalidad de las misiones legislativas.

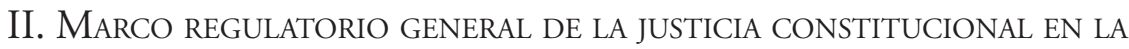 CONSTITUCIÓN DE LA REPÚBLICA DOMINICANA DE 2010}

\section{Base normativa de la justicia constitucional en la Constitución de 2010 y el sistema mixto o integral de justicia constitucional}

Como todas las Constituciones del mundo contemporáneo, la Constitución de la República Dominicana está revestida de supremacía en el ordenamiento jurídico, a cuyo efecto en su propio texto se indica que:

"Todas las personas y los órganos que ejercen potestades públicas están sujetos a la Constitución, norma suprema y fundamento del ordenamiento jurídico del Estado" (Art. 6o).

En la Constitución se regula, además, la garantía objetiva de la misma, al indicar que:

"son nulos de pleno derecho toda ley, decreto, resolución, reglamento o acto contrarios a esta Constitución" (Art. 60).

Estos principios se complementan en la Ley Orgánica al disponer el principio de "inconvalibilidad", en el sentido de que:

"la infracción de los valores, principios y reglas constitucionales está sancionada con la nulidad y se prohibe su subsanación o convalidación" (Art. 7.7)

La inconstitucionalidad, por tanto, no sólo se produce por violación directa de las normas constitucionales, sino de los valores, principios y reglas constitucionales, como lo indica artículo $6^{\circ}$ de la Ley Orgánica, la Constitución se tiene por infringida:

"cuando haya contradicción del texto de la norma, acto u omisión cuestionado, de sus efectos o de su interpretación o aplicación con los valores, principios y reglas contenidos en la Constitución y en los tratados internacionales sobre derechos humanos suscritos y ratificados por la República Dominicana o cuando los mismos tengan como consecuencia restar efectividad a los principios y mandatos contenidos en los mismos".

Para asegurar la supremacía normativa de la Constitución por sobre todo acto estatal, es decir, sobre todo acto dictado en ejercicio del Poder Público, incluyendo, por supuesto, las leyes y demás actos del Congreso, como se dijo, la propia Constitución ha establecido un marco general de la justicia constitucional, atribuyendo, 
por una parte, al Tribunal Constitucional en República Dominicana, competencia para ejercer tal control de constitucionalidad de dichos actos legislativos y otros actos estatales (Art. 185,1), con potestad para anularlos cuando sean inconstitucionales; y además, por la otra, asignando a todos los tribunales competencia para declarar dichos actos como inconstitucionales e inaplicarlos en los casos concretos que decidan (Art. 188). Como parte integrante de dicho control de constitucionalidad, está, por supuesto, el control de convencionalidad en relación con los tratados en materia de derechos humanos, ya que la Ley orgánica precisa que también hay infracción constitucional cuando se violan las normas, valores y reglas de los tratados.

Se trata, por tanto, como dijimos, de un sistema mixto o integral de justicia constitucional que combina el control difuso con el control concentrado de la constitucionalidad y convencionalidad adoptado en otros países latinoamericanos como Colombia, Venezuela, Perú, Brasil, Ecuador, Guatemala, Nicaragua y México.

La consecuencia de ello es que en República Dominicana, al contrario de los que sucede, por ejemplo, en países como Costa Rica o Panamá, la justicia constitucional no se concentra en un solo órgano que conforma la "Jurisdicción Constitucional” como el Tribunal Constitucional, sino que se ejerce por éste y por todos los órganos judiciales.

Se distingue, entonces, en la República Dominicana, la "justicia constitucional" de la "Jurisdicción Constitucional". Esta última es una noción de carácter orgánico, que identifica un órgano estatal judicial o no que ejerce el control concentrado de la constitucionalidad de las leyes y demás actos normativos generalmente dictados de ejecución inmediata de la Constitución, con poderes anulatorios de las mismas, y que por ello, no tiene el monopolio de la "justicia constitucional".

En cambio, la noción de "justicia constitucional” es una noción material equiparable a "control de constitucionalidad", la cual, como se ha dicho, además de por el Tribunal Constitucional, también se ejerce por todos los jueces u órganos jurisdiccionales mediante el método difuso de control de constitucionalidad. Así se precisa en el artículo $5^{\circ}$ de la Ley Orgánica al disponerse que

"La justicia constitucional es la potestad del Tribunal Constitucional y del Poder Judicial de pronunciarse en materia constitucional en los asuntos de su competencia. Se realiza mediante procesos y procedimientos jurisdiccionales que tienen como objetivo sancionar las infracciones constitucionales para garantizar la supremacía, integridad y eficacia y defensa del orden constitucional, su adecuada interpretación y la protección efectiva de los derechos fundamentales" (Art. 50)

Por ello, en la Constitución, además de crearse el Tribunal Constitucional como "Jurisdicción Constitucional", se regulan las competencias en materia de justicia constitucional que ejercen los demás tribunales de la República, al decidir 
las excepciones de inconstitucionalidad cuando ejercen el método de control difuso de la constitucionalidad de las leyes, y al decidir los procesos iniciados mediante las acciones de habeas corpus, amparo o habeas data.

En resumen, la noción de justicia constitucional es de carácter material o sustantiva y se refiere a la competencia que ejercen todos los órganos judiciales cuando les corresponde decidir casos concretos o juicios de amparo aplicando y garantizando la Constitución; en tanto que la expresión Jurisdicción Constitucional es, en cambio, de carácter orgánica, e identifica al órgano jurisdiccional al cual se ha atribuido en la Constitución competencia exclusiva en materia de control concentrado de la constitucionalidad de las leyes, y que es el Tribunal Constitucional.

Esta distinción, en todo caso, se acoge en la Ley Orgánica cuando dispone en el artículo $2^{\circ}$ que la misma tiene como finalidad, no sólo reglar "la organización del Tribunal Constitucional", el cual conforme al artículo $3^{\circ}$ ejerce sus funciones como Jurisdicción Constitucional; sino regular "el ejercicio de la justicia constitucional", la cual como hemos dicho se define en el artículo $5^{\circ}$ como la potestad de los tribunales ("del Tribunal Constitucional y del Poder judicial") "de pronunciarse en materia constitucional en los asuntos de su competencia", la cual "se realiza mediante procesos y procedimientos constitucionales que tienen como objetivo sancionar las infracciones constitucionales para garantizar la supremacía, integridad y eficacia de la Constitución, la defensa del orden constitucional, la adecuada interpretación constitucional y la protección efectiva de los derechos fundamentales". En el mismo sentido, en el artículo $2^{\circ}$ de la Ley Orgánica se insiste en que la justicia constitucional es "para garantizar la supremacía y defensa de las normas y principios constitucionales y del Derecho Internacional vigente en la República, su uniforme interpretación y aplicación, así como los derechos y libertades fundamentales consagrados en la Constitución o en los instrumentos internacionales de derechos humanos aplicables".

En este mismo sentido, por otra parte, es que se define la expresión "constitucionalidad" en el artículo 7.3 de la Ley Orgánica, al declarar que:

"Corresponde al Tribunal Constitucional y al Poder Judicial, en el marco de sus respectivas competencias, garantizar la supremacia, integridad y eficacia de la Constitución y del bloque de constitucionalidad".

Por su parte, en cuanto al bloque de constitucionalidad, "que sirve de parámetro al control de la constitucionalidad y al cual está sujeta la validez formal y material de las normas infraconstitucionales", conforme al artículo 7.10 de la Ley Orgánica, está integrado por:

"los valores, principios y reglas contenidos en la Constitución y en los tratados internacionales sobre derechos humanos adoptados por los poderes públicos de la República Dominicana, 
conjuntamente con los derechos y garantías fundamentales de igual naturaleza a los expresamente contenidos en aquéllos".

En esta forma puede decirse que se materializa en la Ley Orgánica, la previsión del artículo 74,3 de la Constitución que otorga jerarquía internacional a los "tratados, pactos y convenciones relativos a derechos humanos, suscritos y ratificados por el Estado dominicano", los cuales son, por tanto, "de aplicación directa e inmediata por los tribunales y demás órganos del Estado". Por ello, como se dijo, en materia de derechos humanos, el control de constitucionalidad a cargo del Tribunal Constitucional y de los tribunales de la República, es además un control de convencionalidad.

En todo caso, todo este sistema mixto o integral de justicia constitucional en la Constitución de 2010 se concretiza en las previsiones expresas relativas al control concentrado de la constitucionalidad, al control difuso de la constitucionalidad $\mathrm{y}$ a los procesos de protección de los derechos fundamentales.

\section{El control difuso de la constitucionalidad en la Constitución de 2010}

En lo que se refiere al control difuso de la constitucionalidad, la Constitución de la República Dominicana lo reguló, en paralelo al control concentrado, al disponer en su artículo 188 que:

"Los tribunales de la República conocerán la excepción de constitucionalidad en los asuntos sometidos a su conocimiento".

En estos casos, por tanto, todos los tribunales de la República tienen el carácter de jueces constitucionales cuando al resolver un caso concreto sobre el cual tengan conocimiento, declaren la inconstitucionalidad de una norma (el juez la considera "nula"), como si la misma nunca se hubiese dictado (ab inicio), y por tanto, la desapliquen al decidir el caso concreto. En estos casos, por supuesto, el juez no anula la ley cuestionada, competencia que está reservada al Tribunal Constitucional.

En este supuesto, la consideración de la ley aplicable al caso como inconstitucional con efectos retroactivos, debería permitir al juez, también, graduar dichos efectos, como es en general aceptado en el derecho comparado, en materia penal o sancionatoria si se trata de previsiones más favorables, o de respeto a ciertos derechos adquiridos.

\section{El control concentrado de la constitucionalidad en la Constitución de 2010}

El sistema de control concentrado de la constitucionalidad se establece en la Constitución mediante la regulación en el propio texto constitucional, en forma expresa, de la acción de inconstitucionalidad, del control a priori de la constitucio- 
nalidad de los tratados internacionales, de los procesos de resolución de conflictos constitucionales entre órganos del Estado y del control de constitucionalidad de las omisiones legislativas. En forma indirecta, también se abre posibilidad en la Constitución para la estructuración del control de la constitucionalidad de la actuación de los partidos políticos.

A tal efecto, el artículo 184 de la Constitución creó el Tribunal Constitucional "para garantizar la supremacía de la Constitución, la defensa del orden constitucional y la protección de los derechos fundamentales", al cual conforme al artículo $9^{\circ}$ de la Ley Orgánica, le corresponde conocer de los casos previstos por el artículo 185 de la Constitución y de los que se le atribuyen en la Ley Orgánica, teniendo además competencia para conocer "de las cuestiones incidentales que surjan ante él y dirimirá las dificultades relativas a la ejecución de sus decisiones".

\section{A. Acción de inconstitucionalidad}

En lo que se refiere al control concentrado de la constitucionalidad, el artículo 185.1 de la Constitución le atribuye al Tribunal Constitucional como jurisdicción constitucional, competencia para conocer en única instancia de:

"1) Las acciones directas de inconstitucionalidad contra las leyes, decretos, reglamentos, resoluciones y ordenanzas, a instancias del Presidente de la República, de una tercera parte de los miembros del Senado o de la Cámara de Diputados y de cualquier persona con interés legitimo y jurídicamente protegido".

Como consecuencia de esta competencia, el Tribunal Constitucional tiene el poder de anular los actos estatales inconstitucionales con efectos, en principio, hacia el futuro, aun cuando el Tribunal Constitucional tiene competencia para graduarlos y hacerlos retroactivos.

\section{B. El control de constitucionalidad a priori de los tratados internacionales}

Por otra parte, también como mecanismo de control concentrado de constitucionalidad, conforme al artículo 185.2 de la Constitución, el Tribunal Constitucional tiene competencia para conocer en única instancia, del "control preventivo de los tratados internacionales antes de su ratificación por el órgano legislativo".

\section{El control concentrado de los conflictos constitucionales}

Además, en virtud de que el control concentrado de la constitucionalidad tiene por objeto, en particular, asegurar la efectiva vigencia de la parte orgánica de la Constitución, la cual en el mundo moderno y en el Estado democrático siempre se ha construido sobre la base de los principios tanto de la separación orgánica de poderes como de distribución territorial del Poder Público, en la Constitución se 
asigna también al Tribunal Constitucional competencia para resolver los "conflictos de competencia” entre los Poderes Públicos (Art. 185,3).

Estos conflictos son básicamente, los que se originan entre los Poderes Legislativo y Ejecutivo y, además, respecto de los otros órganos constitucionales con autonomía funcional, de manera que todos actúen conforme a los poderes atribuidos en la Constitución, sancionando toda usurpación, por inconstitucionalidad.

Sin embargo, también correspondería al Tribunal Constitucional como órgano encargado del control de la constitucionalidad, mantener el principio de la distribución territorial del poder que establece la Constitución conforme al esquema de descentralización política adoptado, haciendo respetar la autonomía de las entidades municipales que están constitucionalmente establecidas. Por tanto, en el caso de los Municipios que en República Dominicana se dotan de autonomía (Art. 199), los conflictos de competencia también caerían bajo la competencia del Tribunal Constitucional para resolver los conflictos de competencia constitucional entre las entidades territoriales.

\section{El control de las omisiones legislativas absolutas}

La Constitución de 2010 no reguló en forma expresa la potestad del Tribunal Constitucional de controlar la constitucionalidad de las omisiones absolutas del Legislador, como por ejemplo, se regula expresamente en las Constituciones de Brasil, Colombia y Venezuela.

Sin embargo, habiéndose creado el Tribunal Constitucional en el artículo 184 de la Constitución "para garantizar la supremacía de la Constitución, la defensa del orden constitucional y la protección de los derechos fundamentales", sin duda que el mismo, conforme a esta norma, tiene potestad para controlar la constitucionalidad de las omisiones legislativas absolutas, a los efectos de no sólo poder garantizar la supremacía de la Constitución frente a la omisión legislativa en regular mediante ley aspectos sustantivos necesarios para que aquélla tenga efectiva vigencia, sino para la defensa del orden constitucional y además, en particular, para la protección de los derechos fundamentales cuando la omisión legislativa pueda afectar su efectivo ejercicio.

Sobre esto, en todo caso, la Ley Orgánica dispuso al regular la acción directa de inconstitucionalidad, que la misma puede ser interpuesta ante el Tribunal Constitucional, "contra las leyes, decretos, reglamentos, resoluciones y ordenanzas, que infrinjan, por acción u omisión, alguna norma sustantiva" (Art. 36). Igualmente, el artículo $6^{\circ}$ de la Ley Orgánica dispuso que la Constitución también se tiene por infringida "cuando haya contradicción del texto de la norma, acto u omisión cuestionado, de sus efectos o de su interpretación o aplicación con los valores, principios y reglas contenidos en la Constitución". 


\section{E. El control de la constitucionalidad de la actuación de los partidos políticos}

Por último, también formaría parte del objeto del control de la constitucionalidad el velar por el mantenimiento del régimen político democrático, de manera de asegurar que no se rompa; sancionando cualquier actuación que sea contraria a los valores de la democracia que establece la Constitución. Por ello, incluso, en algunos países, los Tribunales Constitucionales tienen competencias para proscribir la actuación de partidos políticos cuyo objeto sea destruir la democracia misma. En la República Dominicana, por ejemplo, la actuación de los partidos debe realizarse "con sujeción a los principios establecidos en esta Constitución (Art. 216), por lo que el control último de la constitucionalidad de la actuación de los partidos políticos también correspondería al Tribunal Constitucional.

\section{El control de constitucionalidad y la garantía de los} derechos fundamentales en la Constitución de 2010

Por otra parte, el control de constitucionalidad también tiene por objeto particular asegurar la vigencia de la parte dogmática de la Constitución, es decir, de los derechos fundamentales declarados en el texto constitucional, y en el caso de la República Dominicana, también los declarados en los tratados internacionales de derechos humanos a los que se da rango constitucional (Art. 74,3).

A estos efectos, en la República Dominicana la Constitución ha establecido acciones específicas de protección como las de amparo, habeas corpus y habeas data (Arts. 70-72), cuyo conocimiento corresponde en forma difusa a los tribunales de la República, consagrándose como principio fundamental en la Ley Orgánica (Art. 7.4), lo que se denomina el principio de "efectividad" en el sentido de que:

"Todo juez o tribunal debe garantizar la efectiva aplicación de las normas constitucionales $y$ de los derechos fundamentales frente a los sujetos obligados o deudores de los mismos, respetando las garantías minimas del debido proceso y está obligado a utilizar los medios más idóneos y adecuados a las necesidades concretas de protección frente a cada cuestión planteada, pudiendo conceder una tutela judicial diferenciada cuando lo amerite el caso en razón de sus peculiaridades".

\section{Principios generales en la Ley Orgánica del Tribunal Constitucional y de los Procedimientos Constitucionales (01/03/2010)}

Conforme al marco constitucional regulatorio de la justicia constitucional antes esbozada, en la Ley Orgánica del Tribunal Constitucional y de los Procedimientos Constitucionales de 2010, se establece el marco regulatorio legislativo 
general de todo el sistema mixto o integral de justicia constitucional de la República Dominicana, conforme a las previsiones que se resumen a continuación.

\section{A. Los diversos procesos constitucionales en la Ley Orgánica}

En la Ley Orgánica, en efecto, se regula, en primer lugar, el control difuso de la constitucionalidad de las leyes y demás actos del Estado.

En segundo lugar, en la Ley Orgánica se regula el control concentrado de la constitucionalidad, previéndose la competencia del Tribunal Constitucional para conocer del proceso constitucional el control a posteriori de la constitucionalidad de las leyes y otros actos estadales, el cual se ejerce mediante la acción de inconstitucionalidad; el procedimiento constitucional del control a priori en relación específicamente con los tratados internacionales, y el proceso constitucional de la resolución de conflictos constitucionales.

En tercer lugar, en la Ley Orgánica también se regula en forma detallada, el régimen general de la garantía judicial de los derechos fundamentales, regulándose los procesos constitucionales en materia de habeas corpus, habeas data y amparo, a cuyo efecto se deroga la Ley número 437-06 de Recurso de Amparo de fecha 30 de noviembre del año 2006.

En cuarto lugar, en la Ley Orgánica también se establecen algunas previsiones, aun cuando incompletas, relativas al control de constitucionalidad de las omisiones absolutas del Legislador.

Y en quinto lugar, también se establecen en la Ley Orgánica previsiones destinadas a regular la potestad del Tribunal Constitucional de revisión de sentencias en materia constitucional, y de conocer en segunda instancia de los casos de amparo, habeas corpus y habeas data vía un recurso de revisión.

\section{B. El principio de la progresividad en materia de derechos fundamentales}

En todos los procesos constitucionales que se regulan en la Ley Orgánica en los cuales esté en juego la protección de los derechos fundamentales, en la misma se ha establecido como principio rector que debe guiar los mismos, el principio de la progresividad o principio pro homine, que se denomina como principio de "favorabilidad" (Art. 7.5), en el sentido de que se declara, primero, que "ninguna disposición de la presente ley puede ser interpretada en el sentido de limitar o suprimir el goce y ejercicio de los derechos y garantías fundamentales", y segundo, que los jueces y funcionarios tienen el deber de interpretar y aplicar la Constitución y los derechos fundamentales de modo que se "optimice su máxima efectividad para favorecer al titular del derecho fundamental". La consecuencia del principio es que "cuando exista conflicto entre normas integrantes del bloque 
de constitucionalidad" debe prevalecer "la que sea más favorable al titular del derecho vulnerado", agregándose que: "Si una norma infraconstitucional es más favorable para el titular del derecho fundamental que las normas del bloque de constitucionalidad la primera se aplicará de forma complementaria, de manera tal que se asegure el máximo nivel de protección”.

\section{Los principios rectores de carácter adjetivo del conjunto de procesos constitucionales}

Respecto de todos estos procesos y procedimientos constitucionales, la Ley Orgánica, por otra parte, ha establecido en su artículo $7^{\circ}$, un conjunto de principios rectores de carácter adjetivo, entre los cuales se destacan los siguientes:

En primer lugar, el principio de "accesibilidad" (Art. 7.1), conforme al cual la jurisdicción debe estar "libre de obstáculos, impedimentos, formalismos o ritualismos que limiten irrazonablemente la accesibilidad y oportunidad de la justicia”.

En segundo lugar, el principio de la "celeridad" (Art. 7.2), conforme al cual, "los procesos de justicia constitucional, en especial los de tutela de los derechos fundamentales deben resolverse dentro de los plazos constitucional y legalmente previstos y sin demora innecesaria”.

En tercer lugar, el principio de "informalidad" (Art. 7.9), en el sentido de que los procesos y procedimientos constitucionales "deben estar exentos de formalismos o rigores innecesarios que afecten la tutela judicial efectiva".

En cuarto lugar, el principio de la "gratuidad" (Art. 7.6), precisando que "la justicia constitucional no está condicionada a sellos, fianzas o gastos de cualquier naturaleza que dificulten su acceso o efectividad y no está sujeta al pago de costas, salvo la excepción de inconstitucionalidad cuando aplique".

En quinto lugar, el principio de la "inderogabilidad" (Art. 7.8), disponiéndose que los procesos constitucionales "no se suspenden durante los estados de excepción y, en consecuencia, los actos adoptados que vulneren derechos protegidos o que afecten irrazonablemente derechos suspendidos, están sujetos al control jurisdiccional”.

Y en sexto lugar, el principio de la "supletoriedad" (Art. 2.13), en el sentido de que para la solución de toda "imprevisión, oscuridad, insuficiencia o ambigüedad" de la ley, se deben aplicar supletoriamente "los principios generales del Derecho Procesal Constitucional y sólo subsidiariamente las normas procesales afines a la materia discutida, siempre y cuando no contradigan los fines de los procesos y procedimientos constitucionales y los ayuden a su mejor desarrollo". 


\section{EL RÉGIMEN DEL CONTROL DIFUSO DE LA CONSTITUCIONALIDAD}

\section{DE LAS LEYES Y DEMÁS ACTOS ESTATALES}

Como se dijo, el artículo 188 de la Constitución regula el "control difuso" de la constitucionalidad, al atribuir a los tribunales de la República competencia para conocer de la "excepción de constitucionalidad" en los asuntos sometidos a su conocimiento"; control que también podría consistir en un control de convencionalidad, en virtud de la jerarquía constitucional de los tratados, pactos y convenciones relativos a derechos humanos, suscritos y ratificados por el Estado dominicano que, además, son de aplicación directa e inmediata por los tribunales y demás órganos del Estado (Art. 74.3).

Por ello, en el Considerando Octavo de la Ley Orgánica se definió el control difuso como el poder "otorgado a los tribunales del Poder Judicial, los cuales por disposición de la propia normativa constitucional, tienen la facultad de revisar, en el marco de los procesos sometidos a su consideración, la constitucionalidad del ordenamiento jurídico dominicano"; habiéndose destinado los artículos 51 y 52 de la Ley Orgánica a regular, dentro de las modalidades de "control de constitucionalidad", este control difuso de la constitucionalidad, conforme a las siguientes reglas:

En primer lugar, se trata de un control de la constitucionalidad que puede realizar "todo juez o tribunal del Poder Judicial apoderado del fondo de un asunto" (Art. 51)

En segundo lugar, es un control difuso de objeto amplio, en el sentido de que no sólo se establece respecto de las leyes, sino que procede respecto de tipo de acto estatal como una "ley, decreto, reglamento o acto" (Art. 51). Es decir, ni en la Constitución ni en la Ley se establece que se trate exclusivamente de un control de constitucionalidad de las leyes ni siquiera de los actos normativos. Sin embargo, el control difuso no procede respecto de los Tratados internacionales una vez que se han reputado constitucionales por el Tribunal Constitucional, de manera que el artículo 57, Parágrafo Único de la Ley Orgánica dispone que luego de que hayan sido objeto de control preventivo de constitucionalidad por el Tribunal Constitucional, "ello impide que posteriormente, el mismo sea cuestionado por inconstitucional ante el Tribunal Constitucional o cualquier juez o tribunal por los motivos que valoró el Tribunal Constitucional".

En tercer lugar, la Ley Orgánica dispone que cuando ante un tribunal apoderado del fondo de un asunto "se alegue como medio de defensa la inconstitucionalidad de una ley, decreto, reglamento o acto", dicho tribunal "tiene competencia y está en el deber de examinar, ponderar y decidir la excepción planteada como cuestión previa al resto del caso".

En cuarto lugar, y contrariamente al sistema tradicional derivado del principio dispositivo, en el régimen de la República Dominicana revalorizándose el princi- 
pio de la supremacía constitucional, se establece la posibilidad de que el control difuso de la constitucionalidad se pueda ejercer de oficio por todo juez o tribunal del Poder Judicial, en aquellas causas llamadas a su conocimiento. Se sigue aquí la misma orientación adoptada en el sistema venezolano, a cuyo efecto por una parte se define en la Ley Orgánica, como principio de "oficiosidad", el que:

"Todo juez o tribunal, como garante de la tutela judicial efectiva, debe adoptar de oficio las medidas requeridas para garantizar la supremacía constitucional y el pleno goce de los derechos fundamentales, aunque no hayan sido invocadas por las partes o lo hayan sido erróneamente" (Art. 2.4).

Y por la otra, el artículo 52 de la Ley Orgánica expresamente dispone que:

"El control difuso de la constitucionalidad debe ejercerse por todo juez o tribunal del Poder Judicial, aun de oficio, en aquellas causas sometidas a su conocimiento".

En quinto lugar, cuanto se trate de una decisión que acepte la excepción de inconstitucionalidad y la consecuencia de la misma sea la desestimación de la acción, la sentencia dictada es entonces recurrible ante la instancia superior. En el caso de que la decisión judicial sea de rechazo de la excepción de inconstitucionalidad, en la ley orgánica se dispone que las mismas sólo pueden ser recurridas con la sentencia que recaiga sobre el fondo del asunto (Art. 51, parágrafo único).

Debe mencionarse, por último, que en la versión inicial del Proyecto de Ley sometido al Senado por el Presidente de la República (Art. 30.3) se buscaba regular expresamente los casos en los cuales dentro de los procesos judiciales, fuera la $\mathrm{Su}$ prema Corte de Justicia, o una de sus salas, la que declarase en su sentencia, por vía de excepción, la inconstitucionalidad de una norma, en cuyo caso se proponía que la misma debía remitirse al Tribunal Constitucional para que éste se pronunciase de manera definitiva sobre la conformidad o no a la Constitución de la norma cuestionada, sin perjuicio de la autoridad de cosa juzgada en el caso. Esta propuesta, sin embargo, no fue acogida en el Proyecto aprobado en el Congreso. De haberlo sido, hubiera sido el único caso del ejercicio del control concentrado de constitucionalidad de las leyes y demás normas, por vía incidental, como consecuencia del ejercicio del control difuso de la constitucionalidad de normas por la Corte Suprema.

IV. EL RÉGIMEN DEL CONTROL CONCENTRADO DE LA CONSTITUCIONALIDAD DE LAS LEYES Y DEMÁS ACTOS ESTATALES Y DE LAS OMISIONES LEGISLATIVAS

\section{La acción de inconstitucionalidad}

El control concentrado de la constitucionalidad, como se dijo, en la Ley Orgánica y conforme a la Constitución, se atribuye al Tribunal Constitucional, 
el cual está definido como "el órgano supremo de interpretación y control de la constitucionalidad" (Art. 10).

A tal efecto y siguiendo lo previsto en la Constitución, en la Ley Orgánica se lo concibe como una institución autónoma de los poderes públicos y de los demás órganos del Estado (Art. 1º), por lo cual los jueces integrantes del Tribunal no están sujetos a mandato imperativo ni reciben instrucciones de ninguna autoridad; no incurriendo en responsabilidad por los votos emitidos en el ejercicio de sus funciones (Art. 18). Por ello, el artículo $3^{\circ}$ de la Ley Orgánica expresamente dispone que "en el cumplimiento de sus funciones como jurisdicción constitucional, el Tribunal Constitucional sólo se encuentra sometido a la Constitución, a las normas que integran el bloque de Constitucionalidad, a esta Ley Orgánica y a sus reglamentos".

Conforme a la Constitución, en definitiva, el Tribunal Constitucional fue concebido "con el objetivo de garantizar la supremacía de la Constitución, la defensa del orden constitucional y la protección de los derechos fundamentales" (Considerando Sexto de la Ley), con la competencia para conocer "de los procesos previstos por el artículo 185 de la Constitución”.

\section{A. La competencia del Tribunal Constitucional \\ a. La precisión del objeto de la acción de inconstitucionalidad}

La competencia del Tribunal Constitucional en materia de control concentrado de la constitucionalidad está definida en la Ley Orgánica, en la Sección I ("Del control concentrado de constitucionalidad") del Capítulo I ("Del control de constitucionalidad") del Título II ("De los procesos y procedimientos constitucionales"), estableciéndose que dicho control se ejerce mediante el conocimiento de "la acción directa de inconstitucionalidad" que puede ser interpuesta ante el Tribunal Constitucional "contra las leyes, decretos, reglamentos, resoluciones y ordenanzas, que infrinjan, por acción u omisión, alguna norma sustantiva". (Art. 36). Se entiende, por supuesto, que en esta expresión de infracción de "norma sustantiva", el artículo se está refiriendo a las infracciones constitucionales tal como se definen en el artículo $6^{\circ}$ de la Ley Orgánica.

En el caso de los tratados internacionales, sin embargo, en la Ley Orgánica se dispone que los mismos, luego de que hayan sido objeto de control preventivo de constitucionalidad, y sean reputados como constitucionales, ello impide que los mismos puedan ser cuestionados por inconstitucionales ante el Tribunal Constitucional, por los motivos que valoró el Tribunal Constitucional (artículo 57, párrafo único).

Ahora bien, con esta última excepción, se trata en general, de un control concentrado de constitucionalidad que se regula en la ley en forma universal, que abarca 
materialmente todos los actos del Estado. Ello, sin duda, constituye una disidencia respecto de los sistemas de control concentrados de la constitucionalidad en el derecho comparado, cuyo objeto se limita normalmente a las leyes o demás actos de igual rango y valor (como los decretos leyes), así como respecto de actos de los órganos superiores del Estado dictados en ejecución directa de la Constitución, como por ejemplo serían los interna corporis del Congreso, los actos de gobierno, como los que declaran los estados de excepción, o las resoluciones, por ejemplo dictadas por la Corte Suprema de Justicia.

Es cierto que el artículo 184 de la Constitución atribuye al Tribunal Constitucional competencia para conocer de las "acciones directas de inconstitucionalidad contra las leyes, decretos, reglamentos, resoluciones y ordenanzas", pero también es cierto que la misma Constitución regula la Jurisdicción Contencioso Administrativa, atribuyendo a los Tribunales Superiores Contencioso Administrativos competencia para "conocer de los recursos contenciosos contra los actos, actuaciones y disposiciones de autoridades administrativas contrarias al Derecho como consecuencia de las relaciones entre la Administración del Estado y los particulares, si éstos no son conocidos por los tribunales contencioso administrativos de primera instancia" (Art. 165.2).

Por tanto, esta ley reguladora de la jurisdicción constitucional tendría que haber sido precisamente la que debía establecer con precisión el deslinde de su ámbito u objeto con relación al de la jurisdicción contencioso administrativa, cuyos jueces también son jueces constitucionales, no sólo cuando ejercen el control difuso de la constitucionalidad como cualquier juez en los casos que resuelven, sino cuando anulan actos administrativos por razones de inconstitucionalidad que es una forma de "contrariedad del derecho".

En el caso de la República Dominicana, puede decirse que la jurisdicción constitucional no tiene el monopolio del control concentrado de la constitucionalidad, sino que lo que tiene es el monopolio del control concentrado de la constitucionalidad de ciertos actos estatales, como las leyes y los demás actos estatales de ejecución directa de la Constitución. El control concentrado de la constitucionalidad de los actos administrativos, en cambio, debe seguir bajo la competencia de los tribunales de la jurisdicción contencioso administrativa.

\section{b. El necesario deslinde entre el objeto de la jurisdicción constitucional y la jurisdicción contencioso administrativa}

El necesario deslinde de estas competencias entre los tribunales de las dos jurisdicciones, la constitucional y la contencioso administrativa, deberá ser, sin duda, una de las tareas iniciales del Tribunal Constitucional, lo que deberá hacer, como ha ocurrido en general en el derecho comparado, basándose en la naturaleza de 
los actos impugnados y no en los motivos de impugnación. Para ello, insistimos, resultan fundamentales las previsiones de la Constitución.

En cuanto a la jurisdicción contencioso administrativa, la competencia de los tribunales de la misma es para conocer de la impugnación de los actos administrativos, o como lo dice el artículo 165,2 de la Constitución, de "los actos, actuaciones y disposiciones de autoridades administrativas contrarias al Derecho como consecuencia de las relaciones entre la Administración del Estado y los particulares", por contrariedad al Derecho, es decir, por vicios de inconstitucionalidad o de legalidad propiamente dicha. Por supuesto, la clave de esta norma está en determinar, primero, si los actos administrativos normativos, como los reglamentos, se consideran o no como actos administrativos; y además, segundo, si hay actos administrativos que puedan estar excluidos del control contencioso administrativo, lo que en principio parece no permitir la norma.

En cuanto a la jurisdicción constitucional, la competencia del Tribunal Constitucional es para conocer de las "acciones directas de inconstitucionalidad contra las leyes, decretos, reglamentos, resoluciones y ordenanzas", tal como lo establece el artículo 185,2 de la Constitución. Ahora bien, es en esta materia que el Tribunal Constitucional deberá interpretar la Constitución para distribuir la competencia entre ambas jurisdicciones, pues si se atiene literalmente al texto, algunos "decretos, reglamentos, resoluciones y ordenanzas" pueden ser considerados o contener actos administrativos, y otros no.

Es decir, en ausencia de una precisa determinación legal por el legislador, deberá ser el Tribunal Constitucional el que precise cuándo algunos "decretos, reglamentos, resoluciones y ordenanzas" son meros actos administrativos y por tanto, sujetos al control de la jurisdicción contencioso administrativa; y cuándo otros "decretos, reglamentos, resoluciones y ordenanzas" no son actos administrativos y por tanto, sujetos al control de la jurisdicción constitucional; y la clave para ello no es otra que la interpretación del sistema jurídico conforme a la doctrina de la creación del derecho por grados (Kelsen, Merkl), de manera que llámense como se llamen los actos estatales, deberían estar sometidos al control de la jurisdicción constitucional, aquellos actos estatales, como lo son las leyes, dictados en ejecución directa e inmediata de la Constitución o de previsiones constitucionales, con rango legal en la formación del orden jurídico. Del resto, los otros actos estatales serían de rango sub-legal como los actos administrativos, dictados en ejecución directa de la legislación (e indirecta de la Constitución) y, por tanto, sometidos al control de la jurisdicción contencioso administrativa

Esto implica que el criterio de distinción entre la jurisdicción constitucional y la jurisdicción contencioso administrativa, debe establecerse con claridad con base en la naturaleza de los actos impugnados, independientemente de su deno- 
minación formal o de su forma jurídica, y por supuesto, de ninguna manera con base en los motivos de impugnación, pues los motivos de inconstitucionalidad se pueden formular en ambas jurisdicciones.

De acuerdo con el artículo 139 de la Constitución, el control de "legalidad" de los actos de la administración pública lo ejercen los tribunales, y en particular, los de la jurisdicción contencioso administrativa, que deben conocer de los recursos contenciosos contra los actos, actuaciones y disposiciones de autoridades administrativas "contrarias al Derecho" realizadas como consecuencia de las relaciones entre la Administración del Estado y los particulares (artículo 165,2). Y "contrariedad al derecho" implica contrariedad a la Constitución y, además, a las leyes y demás fuentes de derecho, por lo que la impugnación de los actos administrativos por razón de inconstitucionalidad, es una competencia exclusiva de los tribunales de la jurisdicción contencioso administrativa y no puede corresponder a la jurisdicción constitucional.

Por tanto, como se dijo, frente a los "decretos, resoluciones y ordenanzas" debe precisarse si en cada caso se trata o no de actos administrativos, pues si se trata de actos administrativos, la competencia para conocer de su impugnación corresponde a los tribunales de la jurisdicción contencioso administrativa aun cuando los motivos de impugnación sean de inconstitucionalidad. Sólo en el caso de los "reglamentos", sin embargo, en particular los dictados por el Presidente de la República (Reglamentos Ejecutivos), aun tratándose de actos administrativos, en virtud de la mención expresa de la Constitución, podrían considerarse que como excepción, la competencia para conocer de su impugnación corresponde en forma exclusiva a la jurisdicción constitucional. Pero ello no debería aplicarse a reglamentos es decir, actos normativos dictados por otros funcionarios de la Administración.

En nuestro criterio, por ejemplo, en la Ley Orgánica pudo haberse dispuesto, casuísticamente, que la acción directa de inconstitucionalidad podía ser interpuesta contra las leyes y resoluciones dictados por el Congreso Nacional; contra los reglamentos dictados por el Presidente de la República; contra los decretos ejecutivos y demás resoluciones emanados de los diversos órganos de los poderes públicos y dictados en ejecución directa e inmediata de la Constitución, incluyendo las declaratorias de los estados de excepción; y contra las ordenanzas, como leyes locales municipales; siempre que no se trate de actos administrativos cuya impugnación debe realizarse ante la jurisdicción contencioso administrativa.

En tal sentido, además, debería aclararse en todo caso, que los actos administrativos de efectos particulares sólo pueden ser impugnados ante la jurisdicción contencioso administrativa aun cuando el motivo de impugnación sea su inconstitucionalidad. 
La redacción de los artículos 184 y 185.1 de la Constitución impone que se interprete la competencia de las dos jurisdicciones en el sentido de que los actos llamados a ser impugnados ante el Tribunal Constitucional (jurisdicción constitucional), con excepción de los reglamentos, sólo deben ser los actos estatales dictados en ejecución directa e inmediata de la Constitución; o en otros términos, que no debe proceder la impugnación ante la jurisdicción constitucional de los actos administrativos, los cuales sólo deben ser impugnados, conforme al artículo 165.2 de la Constitución, ante los tribunales de la jurisdicción contencioso administrativa.

En la enumeración de actos estatales incluida en el artículo 36 de la Ley Orgánica, sin embargo, se sigue a la letra la misma que trae el artículo 185.1 de la Constitución, de la cual resulta, sin duda, unos actos estatales que definitivamente no son actos administrativos, como es el caso de las "leyes" y algunas "resoluciones" que dicta el Congreso Nacional o la Corte Suprema de Justicia.

En cuanto a los "reglamentos," como se dijo, aun siendo actos administrativos, es la Constitución la que prevé su impugnación ante el Tribunal Constitucional, por lo que en ausencia de precisión legal, es el Tribunal Constitucional el llamado a determinar si se trata de cualquier reglamento o acto reglamentario o normativo (que son actos administrativos) o sólo de ciertos reglamentos como los Reglamentos Ejecutivos, es decir, los dictados por el Presidente de la República conforme al artículo 128, 1, b de la Constitución. Todos los otros actos administrativos reglamentarios dictados por cualquier otra autoridad administrativa nacional, provincial o municipal deberían ser impugnables ante los tribunales de la jurisdicción contencioso administrativa.

En cuanto a los otros actos enumerados en la norma del artículo 36 de la Ley Orgánica, también deberá ser el Tribunal Constitucional el que determine en su jurisprudencia interpretativa cuáles se reservan al conocimiento de la jurisdicción constitucional, que deberían ser sólo aquellos dictados en ejecución directa e inmediata de la Constitución. Ello será necesario, por ejemplo, en relación con los "Decretos" que debe presumirse que se refiere a los dictados por el Presidente de la República. Estos, en general, son actos administrativos (impugnables, por tanto, ante la jurisdicción contencioso administrativa), excepto aquellos dictados en ejecución directa e inmediata de la Constitución que serían los únicos que deberían ser impugnables ante la jurisdicción constitucional, como serían muchos de los dictados por el Presidente de la República como Jefe de Estado, por ejemplo, en materia de declaratoria de estados de excepción o estado de defensa nacional conforme al artículo 128, 1 e y f de la Constitución, que serían lo que en otras latitudes se conocen como "actos de gobierno" impugnables ante el Tribunal Constitucional. 
En cuanto a las "Ordenanzas", debe observarse que en la Constitución esa palabra sólo se utiliza precisamente en el artículo 185.2, y no se la usa para calificar ningún acto estatal específico. En la terminología de otros países de América Latina, las Ordenanzas serían las "leyes locales", es decir, los actos normativos dictados por los Concejos Municipales autónomos, en las materias que la Constitución les asigna y reserva, que presumimos es el mismo sentido que tienen en la República Dominicana.

\section{B. La legitimación activa para intentar la acción de inconstitucionalidad}

El artículo 37 de la Ley Orgánica regula la legitimación para interponer la acción de inconstitucionalidad, distinguiendo dos supuestos distintos con criterios diferentes:

\section{a. Legitimación activa del Presidente de la República y de representantes de las Cámaras Legislativas}

En primer lugar, se dispone que la acción directa en inconstitucionalidad puede ser interpuesta a instancias del Presidente de la República o de una tercera parte de los miembros del Senado o de la Cámara de Diputados. En estos casos, la legitimación activa que se regula es específica, sin consideración alguna al interés que puedan tener dichos funcionarios en la impugnación.

\section{b. Legitimación respecto de los ciudadanos: la exigencia de un interés legítimo y protegido}

En segundo lugar, se establece en general que la acción de inconstitucionalidad puede ser impuesta por cualquier persona, "con interés legítimo y jurídicamente protegido" (Art. 37). En consecuencia, sea cual fuere la naturaleza del acto estatal objeto de la impugnación, es decir, trátese o no de un acto estatal de carácter normativo, la condición legal para intentar la acción de inconstitucionalidad es que sólo las personas afectadas por los mismos, y que por tanto, sean titulares de un "interés legítimo", es decir, derivado de un título jurídico y que se encuentre jurídicamente protegido, pueden interponerla.

En esta forma, se eliminó de la Ley Orgánica toda posibilidad de que la acción de inconstitucionalidad se pudiera configurar como una acción popular, que corresponde a todos los ciudadanos por el simple interés en la constitucionalidad, como existe en Colombia y Venezuela. A tal efecto, en el Proyecto enviado al Senado por el Presidente de la República en 2010 (Art. 99), se disponía que frente a los actos normativos se presumía siempre que toda persona tenía un interés legítimo y jurídicamente protegido, con lo que la acción de inconstitucionalidad 
contra los actos normativos, se configuraba como una acción popular, pudiendo cualquier persona interponerla. No estableciéndose en el texto de la Ley Orgánica esta presunción legal, es forzado que se interprete que todo ciudadano siempre tiene "interés legítimo" en la constitucionalidad de los actos estatales, y que dado el principio constitucional de la supremacía, se presuma que por ello ese interés en la constitucionalidad está "jurídicamente protegido".

Nada se estableció expresamente en la Ley Orgánica sobre la posibilidad de acciones de inconstitucionalidad interpuestas contra actos estatales que vulneren derechos colectivos y del medioambiente o intereses colectivos y difusos, por lo que respecto de los mismos se aplica la misma regla del interés legítimo y jurídicamente protegido.

\section{Los principios del procedimiento en el proceso constitucional de anulación}

En cuanto al procedimiento en los procesos de control de constitucionalidad, la Ley Orgánica establece las siguientes reglas principales de procedimiento:

\section{a. Escrito de la demanda}

El escrito mediante el cual se interponga la acción de inconstitucionalidad debe ser presentado ante la Secretaría del Tribunal Constitucional, y en el mismo deben exponerse sus "fundamentos en forma clara y precisa, con cita concreta de las disposiciones constitucionales que se consideren infringidas" (Art. 38).

\section{b. Admisión de la acción}

Si el Presidente del Tribunal Constitucional considera que se han cumplido los requisitos antes indicados, debe decidir sobre la admisión de la acción, debiendo en el auto de admisión de la acción, notificar el escrito al Procurador General de la República y a la autoridad de la que emane la norma o acto cuestionado, para que en el plazo de 30 días a partir de su recepción, manifiesten su opinión al respecto (Art. 39). La falta de dictamen del Procurador o de las observaciones de la autoridad cuya norma o acto se cuestione no impide la tramitación y fallo de la acción en inconstitucionalidad (Art. 39, Parágrafo único).

El Presidente del Tribunal debe igualmente en el mismo acto de admisión, disponer que un extracto de la acción que ha sido incoada se publique en el portal institucional del Tribunal y en cualquier otro medio que se estime pertinente (Art. 40).

En el Proyecto de Ley Orgánica sometido por el Presidente de la República al Senado (Art. 30.16), se había previsto que conjuntamente con la acción de inconstitucionalidad y mediante instancia separada, el accionante podía solicitar 
que mientras se decidiera la acción de inconstitucionalidad de la norma o acto impugnado, el Tribunal Constitucional podía disponer sobre la suspensión de sus efectos, hasta tanto dictara sentencia sobre la acción principal. Esta previsión fue eliminada al sancionarse la Ley Orgánica.

\section{c. Audiencia oral}

Una vez vencido el plazo antes indicado para la manifestación de la opinión del Procurador y de la autoridad de la que emane la norma o acto cuestionado, el Tribunal debe convocar a una audiencia oral y pública, a fin de que el accionante, dicha autoridad y el Procurador presenten sus conclusiones. La no comparecencia de las partes no impide el fallo de la acción en inconstitucionalidad (Art. 41).

En esta forma, al eliminarse de la Ley Orgánica la popularidad de la acción, se eliminó también del procedimiento la posibilidad de intervención de terceros como coadyuvantes en las alegaciones que pudieren justificar la procedencia o improcedencia de la inconstitucionalidad, o para ampliar, en su caso, los motivos de inconstitucionalidad en relación con el asunto que les pudiese interesar, tal como se había dispuesto en el Proyecto de Ley Orgánica que el Presidente de la República sometió al Senado en 2010 (Art. 29.4).

\section{d. Informes técnicos}

El Tribunal Constitucional puede requerir de instituciones públicas o privadas informes técnicos para mejor resolver en ocasión de una acción de inconstitucionalidad (Art. 42).

\section{e. Lapso de decisión}

El Tribunal Constitucional debe resolver la acción de inconstitucionalidad dentro de un término máximo de cuatro (4) meses, a partir de la fecha en que concluya la vista (Art. 43).

\section{Las sentencias del Tribunal Constitucional en materia de control concentrado de constitucionalidad}

La Ley Orgánica establece en el artículo 30, los siguientes tipos de sentencias en los procesos de control de constitucionalidad:

\section{a. Sentencias desestimatorias o de denegación}

En primer lugar, están las sentencias desestimatorias o de denegación de la acción, en las cuales el Tribunal debe examinar todos los motivos de inconstitucionalidad que se hubieren alegado para fundamentarla. 
Estas sentencias únicamente surten efecto entre las partes en el caso concreto y no producen cosa juzgada (Art. 44).

\section{b. Sentencias estimatorias y de anulación}

En segundo lugar, están las sentencias estimatorias o de acogimiento de la acción, que declaran la inconstitucionalidad y que, en consecuencia, disponen la anulación consecuente de la norma o los actos impugnados.

Estas sentencias producen cosa juzgada y eliminan la norma o acto del ordenamiento jurídico, lo que rige "a partir de la publicación de la sentencia" (Art. 45). Esto significa que las sentencias anulatorias del Tribunal Constitucional tienen, en principio, efectos pro futuro, ex nunc; lo que se reafirma en el artículo 48 donde se afirma que "la sentencia que declara la inconstitucionalidad de una norma produce efectos inmediatos y para el porvenir". Sin embargo, la norma autoriza por vía de excepción al Tribunal Constitucional para "reconocer y graduar excepcionalmente, de modo retroactivo, los efectos de sus decisiones de acuerdo a las exigencias del caso".

Estas sentencias que declaran la inconstitucionalidad de una norma o disposición general, deben declarar también la inconstitucionalidad de los demás preceptos de ella, o de cualquier otra norma o disposición cuya anulación resulte evidentemente necesaria por conexidad, así como la de los actos de aplicación cuestionados (Art. 46).

\section{c. Sentencias interpretativas en armonía con la Constitución y de desestimación de la anulación}

En tercer lugar, están las sentencias interpretativas de acuerdo con la Constitución y de desestimación de la anulación, sobre las cuales el artículo 47 dispone que el Tribunal Constitucional, en todos los casos que conozca, puede dictar "sentencias interpretativas de desestimación o rechazo que descartan la demanda de inconstitucionalidad, declarando la constitucionalidad del precepto impugnado, en la medida en que se interprete en el sentido que el Tribunal Constitucional considera como adecuado a la Constitución, o no se interprete en el sentido o sentidos que considera inadecuados". Se trata de las sentencias de interpretación de la ley en armonía con la Constitución evitando su anulación.

\section{d. Sentencias aditivas en los casos de estimación de la omisión legislativa relativa inconstitucional}

En cuarto lugar, están las sentencias aditivas o exhortativas dictadas en los casos de control de la constitucionalidad de omisiones legislativas relativas. En tal sentido, el artículo 47.I dispone expresamente la posibilidad para el Tribunal Constitucional, al controlar la inconstitucionalidad de las omisiones legislativas, 
de dictar sentencias interpretativas de estimación, en las cuales se puede declarar expresamente la inconstitucionalidad parcial de un precepto, sin que dicha inconstitucionalidad afecte a su texto.

Puede tratarse de las llamadas sentencias interpretativas "aditivas", que son las sentencias dictadas cuando el Tribunal considera inconstitucional una omisión legislativa relativa en el sentido amplio de "ausencia de previsión legal expresa de lo que constitucionalmente debía haberse previsto", interpretando la norma en el sentido de contener lo que conforme a la Constitución debía haberse previsto; o realizando una "interpretación extensiva o analógica del precepto impugnado" para cubrir el vacío legislativo (Art. 47.II).

\section{E. El carácter vinculante de las sentencias del Tribunal Constitucional}

Conforme a los principios establecidos en la Constitución (Art. 184), las sentencias del Tribunal Constitucional en materia de control de constitucionalidad, son "definitivas e irrevocables", constituyendo "precedentes vinculantes para todos los poderes públicos y los órganos del Estado" (Considerando Séptimo de la Ley Orgánica), lo que como se ha dicho se precisa en el artículo 7.13 de la Ley Orgánica, y se reitera en el artículo 31 de la misma Ley Orgánica, al disponerse que "las decisiones del Tribunal Constitucional son definitivas e irrevocables y constituyen precedentes vinculantes para los poderes públicos y todos los órganos del Estado". Se prevé en la norma, sin embargo, que el Tribunal Constitucional pude resolver "apartándose de su precedente", en cuyo caso debe expresar en los fundamentos de hecho y de derecho de la decisión "las razones por las cuales ha variado su criterio" (Art. 31.I).

\section{F. Algunas previsiones adjetivas en torno a las sentencias}

La Ley Orgánica, además, en torno a la sentencia, establece las siguientes provisiones generales de carácter adjetivo:

\section{a. Notificación.}

Una vez dictada la sentencia, cualquiera que fuese su forma, se debe notificar siempre; al Procurador General de la República, al accionante y "a las partes que hubieren intervenido" (Art. 49), las que quedan reducidas a la autoridad o autoridades de las que emane la norma o acto cuestionado. Además, la Secretaría del Tribunal Constitucional la debe comunicar por nota a los funcionarios que conozcan del asunto principal y los de las demás partes, para que lo hagan constar en los autos, y debe publicar por tres veces consecutivas un aviso en el Boletín Constitucional así como en el portal institucional del Tribunal (Art. 49.I). La declaración 
de inconstitucionalidad se debe comunicar, además, al poder o poderes, órganos o entidades que emitieron las normas o actos declarados inconstitucionales, así como, en su caso, "a los competentes para su corrección o conversión" (Art. 49.II)

\section{b. Publicación}

El fallo debe publicarse íntegramente en el Boletín Constitucional y reseñarse en un diario de circulación nacional y en las publicaciones oficiales de los textos a que pertenecían la norma o normas anuladas (Art. 49.III).

A tal efecto, el artículo $4^{\circ}$ de la Ley Orgánica precisa que el Boletín Constitucional es el órgano de publicación oficial de los actos del Tribunal Constitucional, debiendo además tener el Tribunal su propio portal institucional.

\section{c. Ejecución}

El Tribunal Constitucional, además, puede disponer en la sentencia, o en actos posteriores, el responsable de ejecutarla y, en su caso, resolver las incidencias de la ejecución (Art. 50) conforme a lo dispuesto en el artículo 87 que regula los poderes del juez de amparo, conforme al cual, por tanto, el Tribunal Constitucional goza de los más amplios poderes para celebrar medidas de instrucción.

\section{El control preventivo de la constitucionalidad de los tratados internacionales}

Conforme al artículo 185.2 de la Constitución, el Tribunal Constitucional tiene competencia para conocer en única instancia, del "control preventivo de los tratados internacionales antes de su ratificación por el órgano legislativo”, razón por la cual en los artículos 55 y siguientes de la Ley Orgánica se regula el procedimiento constitucional, estableciéndose las siguientes reglas:

\section{A. Carácter automático del control}

En primer lugar, se ratifica el carácter preventivo y obligatorio o automático del control, al disponerse que "previo a su ratificación por el Congreso Nacional", el Presidente de la República debe someter los tratados internacionales suscritos por la República al Tribunal Constitucional, "a fin de que éste ejerza sobre ellos el control previo de constitucionalidad” (55).

\section{B. Ambito y competencia del Tribunal}

En segundo lugar, en cuanto a la competencia del Tribunal Constitucional, el artículo 52 dispone que el mismo debe decidir "sobre la constitucionalidad o no de los tratados internacionales suscritos" dentro de los 30 días siguientes a 
su recibo, y, al hacerlo, el Tribunal debe indicar, si considerare que el Tratado es inconstitucional, "sobre cuáles aspectos recae la inconstitucionalidad", así como las razones que fundamentan su decisión.

\section{Efectos de las sentencias}

En tercer lugar, en cuanto a los efectos de la sentencia del Tribunal Constitucional, también se dispone en la Ley Orgánica, por una parte, que la misma es vinculante para el Congreso Nacional y el Poder Ejecutivo (Art. 57); y por la otra, en los casos en los cuales el tratado internacional sea reputado constitucional, la decisión impide que, posteriormente, el mismo tratado sea cuestionado por inconstitucional ante el Tribunal Constitucional o cualquier juez o tribunal por los motivos que valoró el Tribunal Constitucional (Art. 57, párrafo único).

\section{Publicación de las sentencias}

La decisión del Tribunal Constitucional sobre el control preventivo de los tratados, también debe publicarse por los medios oficiales del Tribunal Constitucional (Art. 58), es decir, el Boletín Constitucional y el portal del Tribunal Constitucional (Art. 4o).

\section{El control de la constitucionalidad de las omisiones legislativas absolutas}

Es evidente que al atribuirle, el artículo 184 de la Constitución, al Tribunal Constitucional competencia "para garantizar la supremacía de la Constitución, la defensa del orden constitucional y la protección de los derechos fundamentales", que frente a omisiones legislativas absolutas, el Tribunal tendría competencia para conocer de las denuncias que se formulen al respecto.

La Ley Orgánica, a tal efecto, reguló expresamente la posibilidad de intentar una acción autónoma de inconstitucionalidad contra las omisiones de las leyes (Art. 36), considerando además las omisiones legislativas como infracciones constitucionales (Art. 6).

La consecuencia de ello es la previsión en la Ley Orgánica, al regularse los tipos de sentencias que puede dictar el Tribunal, de las llamadas "sentencias exhortativas", en las cuales requiere o exhorta al legislador para dictar la normativa necesaria para cubrir un vacío legislativo absoluto. En tal sentido, en el artículo 47.III de la Ley Orgánica se incluyó la posibilidad para el Tribunal Constitucional de dictar en estos casos de omisiones legislativas, "cualquier otra modalidad admitida en la práctica constitucional comparada", lo cual abre un campo muy amplio de justicia constitucional, por ejemplo, cuando en las sentencias exhortativas el Tribunal en su mismo texto se establece el régimen legal aplicable, de vigencia temporal hasta que debe regir hasta tanto el legislador dicte la legislación correspondiente. 


\section{4, El control de la constitucionalidad de los conflictos de competencia de orden constitucional}

Conforme al artículo 185.3 de la Constitución, el Tribunal Constitucional tiene competencia para conocer en única instancia de "los conflictos de competencia entre los poderes públicos, a instancia de uno de sus titulares".

\section{A. Naturaleza constitucional del conflicto}

Conforme al artículo 59 de la Ley Orgánica, este control es un control de constitucionalidad, por lo que los conflictos que el Tribunal Constitucional está llamado a resolver son sólo:

"los conflictos de competencia de orden constitucional entre los poderes del Estado, así como los que surjan entre cualesquiera de estos poderes, y entes órganos constitucionales, entidades descentralizadas y autónomas, los municipios u otras personas de Derecho Público, o los de cualesquiera de éstas entre sí, salvo aquellos conflictos que sean de la competencia de otras jurisdicciones en virtud de la Constitución o leyes especiales" (Art. 59).

Por tanto, conflictos meramente administrativos entre órganos o entidades de la Administración sobre competencias no reguladas en la Constitución, se deben someter, por ejemplo, al conocimiento de los tribunales de la jurisdicción contencioso administrativa.

\section{B. Legitimación}

En cuanto a la iniciativa para plantear el conflicto constitucional, la Ley Orgánica dispone que el mismo debe ser planteado "por el titular de cualquiera de los poderes del Estado, órganos o entidades en conflicto", quien debe enviar a la Secretaría del Tribunal Constitucional, "un memorial con una exposición precisa de todas las razones jurídicas en que se fundamente el hecho en cuestión” (Art. 60).

\section{Audiencia}

En cuanto al procedimiento, se dispone en la Ley Orgánica que el Presidente del Tribunal debe dar audiencia al titular del otro poder, órgano o entidad por un plazo improrrogable de 30 días, a partir de la recepción del memorial (Art. 61).

\section{Sentencia}

Una vez cumplido el lapso antes mencionado para la audiencia, aunque no se hubiere contestado la audiencia, el Tribunal debe resolver el conflicto dentro de los siguientes 60 días, salvo que se considere indispensable practicar alguna prue- 
ba, en cuyo caso dicho plazo se contará a partir del momento en que ésta se haya practicado (Art. 62). Por supuesto, en este caso, como en todas las sentencias del Tribunal Constitucional, la misma se considera como precedente vinculante.

\section{EL PROCESO CONSTITUCIONAL DE LA REVISIÓN CONSTITUCIONAL DE SENTENCIAS CONSTitucionales ante el Tribunal Constitucional}

La Constitución de 2010 establece, como principio general, en su artículo 277, que todas las decisiones judiciales que hubieran adquirido la autoridad de la cosa irrevocablemente juzgada, especialmente las dictadas en ejercicio del control directo de la constitucionalidad por la Suprema Corte de Justicia, hasta el momento de la proclamación de la Constitución (enero 2010), no pueden ser examinadas por el Tribunal Constitucional.

En cambio, dispuso la norma en relación con las sentencias dictadas con posterioridad a la entrada en vigencia de la Constitución, que las mismas están "sujetas al procedimiento que determine la ley que rija la materia".

Se estableció así, indirectamente, la posibilidad para el Tribunal Constitucional de revisar sentencias definitivamente firmes por motivos de inconstitucionalidad.

\section{Previsión legal}

Fue por tanto conforme a esta autorización constitucional que en la Ley Orgánica se ha previsto un procedimiento para la "revisión constitucional de las decisiones constitucionales", conforme al cual, tal como lo dispone el artículo 53, el Tribunal Constitucional tiene "la potestad de revisar las decisiones jurisdiccionales que hayan adquirido la autoridad de la cosa irrevocablemente juzgada con posterioridad al 26 de enero de 2010, fecha de proclamación y entrada en vigencia de la Constitución", en las cuales se haya resuelto alguna cuestión constitucional.

El fundamento de este procedimiento de revisión constiucional de sentencias constitucionales, se expresó en los Considerandos Noveno y Décimo de la Ley Orgánica, al declarar lo siguiente:

"Considerando Noveno: Que se hace necesario establecer un mecanismo jurisdiccional a través del cual se garantice la coherencia y unidad de la jurisprudencia constitucional, siempre evitando la utilización de los mismos en perjuicio del debido proceso y la seguridad jurídica;

Considerando Décimo: Que en tal virtud, el artículo 277 de la Constitución de la República atribuyó a la ley la potestad de establecer las disposiciones necesarias para asegurar la adecuada protección y armonización de los bienes jurídicos envueltos en la sinergia institucional que debe darse entre el Tribunal Constitucional y el Poder Judicial, tales como la independencia judicial, la seguridad jurídica derivada de la adquisición de la 
autoridad de cosa juzgada y la necesidad de asegurar el establecimiento de criterios uniformes que garanticen en un grado máximo la supremacía constitucional y la protección de los derechos fundamentales".

\section{Supuestos de decisiones judiciales sujetas a revisión constitucional}

De acuerdo con estas declaraciones y con el mismo artículo 53 de la Ley Orgánica que está destinado a regular la "revisión constitucional de decisiones jurisdiccionales", sujeto a la limitación temporal antes mencionada así como al carácter de sentencia que ha adquirido autoridad de cosa irrevocablemente juzgada, la revisión procede respecto de las siguientes:

\section{A. Sentencias dictadas en materia de control difuso de la constitucionalidad}

En primer lugar, cuando se trate de decisiones judiciales que "declaren inaplicables por inconstitucional una ley, decreto, reglamento, resolución u ordenanza”, en un caso concreto, es decir, en los casos de sentencias en las cuales se ejerza el control difuso de la constitucionalidad.

\section{B. Sentencias que violen un precedente del Tribunal Constitucional}

En segundo lugar, cuando se trate de decisiones judiciales en las cuales se "viole un precedente del Tribunal Constitucional”.

Siendo las sentencias del Tribunal Constitucional precedentes vinculantes, cuando una decisión judicial viole tal precedente su revisión constitucional.

\section{Sentencias que violen derechos fundamentales}

En tercer lugar, cuando se trate de sentencias en las cuales "se haya producido una violación de un derecho fundamental", siempre que concurran y se cumplan todos y cada uno de los siguientes requisitos:

a. Que el derecho fundamental vulnerado se haya invocado formalmente en el proceso, tan pronto quien invoque la violación haya tomado conocimiento de la misma;

b. Que se hayan agotado todos los recursos disponibles dentro de la vía jurisdiccional correspondiente y que la violación no haya sido subsanada, y

c. Que la violación al derecho fundamental sea imputable de modo inmediato y directo a una acción u omisión del órgano jurisdiccional, con independencia de los hechos que dieron lugar al proceso en que dicha violación se produjo, los cuales el Tribunal Constitucional no podrá revisar.

Debe mencionarse que en este tercer supuesto de revisión constitucional de sentencias, conforme al párrafo único del artículo 53, la revisión sólo es admisible 
por el Tribunal Constitucional cuando éste considere "que, en razón de su especial trascendencia o relevancia constitucional, el contenido del recurso de revisión justifique un examen y una decisión sobre el asunto planteado". En estos casos, el Tribunal siempre debe motivar su decisión, lo que se ratifica en el artículo 31, párrafo II, al indicar en general que "en los casos en los cuales esta ley establezca el requisito de la relevancia o trascendencia constitucional como condición de recibilidad de la acción o recurso, el Tribunal debe hacer constar en su decisión los motivos que justifican la admisión".

\section{Sentencias de amparo constitucional}

En cuarto lugar, debe mencionarse en materia de las sentencias constitucionales sujetas a revisión por el Tribunal Constitucional, que también estarían las sentencias de amparo, aun cuando la revisión en este caso no se produzca mediante el recurso previsto en los artículos 53 y siguientes de la Ley Orgánica, sino mediante el recurso de revisión establecido en los artículos 94 y siguientes de la misma Ley Orgánica.

En estos casos, ciertamente, se regula la competencia del Tribunal Constitucional para conocer en segunda instancia (revisión o apelación) de las sentencias de primera instancia dictadas en materia de amparo, y si bien la revisión no es, por tanto, en principio, sólo de orden constitucional, pues comprende el conocimiento de la causa, uno de los motivos fundamentales de revisión es de tipo constitucional, al punto de que se establece como requisito de admisibilidad del recurso de revisión, a la existencia de una "especial trascendencia o relevancia constitucional de la cuestión planteada, que se apreciará atendiendo a su importancia para la interpretación, aplicación y general eficacia de la Constitución, o para la determinación del contenido, alcance y la concreta protección de los derechos fundamentales" (Art. 100).

\section{Legitimación activa}

Aun cuando la Ley Orgánica no estableció expresamente las condiciones de legitimación para intentar el recurso, se entiende que la misma corresponde a quienes hayan sido parte en el proceso jurisdiccional correspondiente.

\section{Normas generales de procedimiento}

El artículo 54 de la Ley Orgánica establece las siguientes normas básicas de procedimiento a seguir en materia de revisión constitucional de las decisiones jurisdiccionales: 


\section{A. Lapso para recurrir y escrito del recurso}

El recurso de revisión constitucional debe interponerse mediante escrito motivado, que debe ser depositado en la secretaría del tribunal que dictó la sentencia recurrida, en un plazo no mayor de treinta días a partir de la notificación de la sentencia (Art. 54.1).

\section{B. Notificación a las partes y escrito de defensa}

El escrito contentivo del recurso debe ser notificado a las partes que participaron en el proceso resuelto mediante la sentencia recurrida, en un plazo no mayor de cinco días a partir de la fecha de su depósito (Art. 54.2).

La otra parte del proceso, o "el recurrido" debe depositar el escrito de defensa en la secretaría del tribunal que dictó la sentencia, en un plazo no mayor de treinta días a partir de la fecha de la notificación del recurso. Este escrito de defensa debe ser notificado "al recurrente" en un plazo de cinco días contados a partir de la fecha de su depósito (Art. 54.3).

\section{Remisión del expediente al Tribunal Constitucional y la decisión sobre la admisibilidad}

El tribunal que dictó la sentencia recurrida debe remitir a la Secretaría del Tribunal Constitucional copia certificada de la misma, así como de los escritos correspondientes presentados por las partes en un plazo no mayor de diez días contados a partir de la fecha de vencimiento del plazo para el depósito del escrito de defensa. Las partes ligadas en el diferendo pueden diligenciar la tramitación de los documentos anteriormente indicados, en interés de que la revisión sea conocida, con la celeridad que requiere el control de la constitucionalidad (Art. 54.4).

El recurso de revisión no tiene efecto suspensivo, salvo que, a petición, debidamente motivada, de parte interesada, el Tribunal Constitucional disponga expresamente lo contrario (Art. 54.8)

Una vez recibidos los recaudos en el Tribunal Constitucional, el mismo tiene un plazo no mayor de 30 días, a partir de la fecha de la recepción del expediente, para decidir sobre la admisibilidad del recurso, estando obligado a motivar su decisión "en caso de que decida admitirlo" (Art. 54.5).

\section{La sentencia de revisión y su efecto}

El Tribunal Constitucional debe realizar la revisión en "Cámara de Consejo, sin necesidad de celebrar audiencia" (Art. 54.6), debiendo dictar sentencia de revisión en un plazo no mayor de 90 días contados a partir de la fecha de la decisión sobre la admisibilidad del recurso (Art. 54.7). 
La decisión del Tribunal Constitucional que acogiere el recurso, debe anular la sentencia objeto del mismo y el Tribunal Constitucional debe devolver el expediente a la secretaría del tribunal que la dictó (Art. 54.9).

\section{E. La nueva decisión judicial}

Con motivo de la devolución del expediente al tribunal que dictó la sentencia recurrida, éste deberá conocer nuevamente del caso, con estricto apego al criterio establecido por el Tribunal Constitucional en relación del derecho fundamental violado o a la constitucionalidad o inconstitucionalidad de la norma cuestionada por la vía difusa (Art. 54.10).

\section{EL PROCEDIMIENTO DE REVISIÓN DE LAS SENTENCIAS DE AMPARO ANTE EL TRIBUNAL CONSTITUCIONAL}

Como se dijo, de acuerdo con el artículo 94 de la Ley Orgánica, los procesos de amparo se desarrollan en dos instancias, siendo la segunda instancia el Tribunal Constitucional, razón por la cual, "todas las sentencias emitidas por el juez de amparo pueden ser recurridas en revisión por ante el Tribunal Constitucional". En consecuencia, ningún otro recurso es posible, salvo la tercería, en cuyo caso debe procederse "con arreglo a lo que establece el derecho común" (Art. 94, párrafo único).

\section{Escrito de interposición del recurso}

El recurso de revisión de las sentencias de amparo se debe interponer mediante escrito motivado, que debe ser depositado en la secretaría del juez o tribunal que rindió la sentencia, en un plazo de cinco (5) días contados a partir de la fecha de su notificación (Art. 95).

Dicho escrito debe contener las menciones exigidas para la interposición de la acción de amparo, haciéndose constar además de forma clara y precisa los agravios causados por la decisión impugnada (Art. 96).

\section{Notificación y escrito de defensa}

El recurso de revisión interpuesto debe ser notificado a las demás partes en el proceso, junto con las pruebas anexas, en un plazo no mayor de cinco (5) días (Art. 97); de manera que en el plazo de cinco (5) días contados a partir de dicha notificación del recurso, las demás partes en el proceso deben depositar en la secretaría del juez o tribunal que rindió la sentencia, su escrito de defensa, junto con las pruebas que lo avalan (Art. 98). 


\section{Remisión al Tribunal Constitucional y requisitos de admisibilidad vinculados a la trascendencia constitucional de la cuestión}

$\mathrm{Al}$ vencerse el plazo para la presentación del escrito de defensa, la secretaría de juez o tribunal debe remitir sin demora el expediente conformado al Tribunal Constitucional (Art. 99), a los efectos de que éste decida sobre la admisibilidad del recurso.

Se destaca, a este respecto, que la admisibilidad de los recursos de revisión contra las sentencias de amparo es limitada, sólo cuando existan cuestiones constitucionales y más específicamente, cuando haya "especial trascendencia o relevancia constitucional de la cuestión planteada", lo cual se debe apreciar por el Tribunal Constitucional, "atendiendo a su importancia para la interpretación, aplicación y general eficacia de la Constitución, o para la determinación del contenido, alcance y la concreta protección de los derechos fundamentales" (Art. 100).

\section{Audiencia y sentencia}

En el curso del procedimiento que se sigue ante el Tribunal Constitucional, la posibilidad de convocar a una audiencia pública para una mejor sustanciación del caso, queda a juicio del Tribunal Constitucional, si "lo considera necesario" (Art. 101).

La sentencia del Tribunal Constitucional sobre el recurso de revisión de las sentencias de amparo debe pronunciarse dentro del plazo máximo de 30 días que sigan a la recepción de las actuaciones (Art. 102).

Santo Domingo, 3 de marzo de 2011. 
